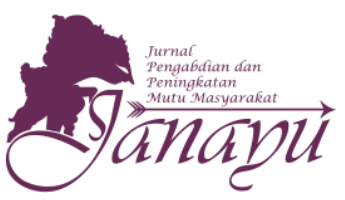

Website:

ejournal.umm.ac.id/index.php/janayu

*Correspondence:

kukuhdwik@gmail.com

DOI: $10.22219 /$ janayu.v2i2.15675

Sitasi:

Kurniawan, K.D., \& Hapsari, D.R.I. (2021). Pendampingan Masyarakat

Dusun Klandungan Desa

Landungsari Kecamatan Dau

Kabupaten Malang Atas Dampak

Pembangunan Penginapan. Jurnal

Pengabdian dan Peningkatan Mutu

Masyarakat, 2(2), 114-122.

Proses Artikel

Diajukan:

8 April 2021

Direviu:

7 Mei 2021

Direvisi:

3 Juli 2021

Diterima:

4 Juli 2021

Diterbitkan:

8 Juli 2021

\author{
Alamat Kantor: \\ Jurusan Akuntansi Universitas \\ Muhammadiyah Malang \\ Gedung Kuliah Bersama 2 \\ Lantai 3. \\ Jalan Raya Tlogomas 246, \\ Malang, Jawa Timur, \\ Indonesia
}

P-ISSN: 2721-0421

E-ISSN: 2721-0340
Tipe Artikel: Paper Pengabdian

\section{Pendampingan Masyarakat Dusun Klandungan Desa Landungsari Kecamatan Dau Kabupaten Malang Atas Dampak Pembangunan Penginapan}

\author{
Kukuh Dwi Kurniawan $^{1 *}$, Dwi Ratna Indri Hapsari ${ }^{2}$ \\ Afiliasi: \\ 1,2Program Studi Ilmu Hukum, Fakultas Hukum, Universitas \\ Muhammadiyah Malang, Malang, Jawa Timur, Indonesia
}

\section{ABSTRACT}

CSR implementation in Indonesia includes social and environmental responsibility. As felt by the people of Klandungan Hamlet, Landungsari Village, Dau District, Malang Regency, which was affected by the process of building a home stay by a commercial company in Malang Regency. There is a need for a symbiotic mutualism relationship between business actors in running their businesses and the community can also be able to carry out activities properly in the process of development and operations of the company in the future. The purpose of this service is to provide socialization and assist residents in fulfilling their rights over the development and / or operations of the company so that in the future there will be no conflicts. The method used is to accompany the negotiation meeting of the parties without taking sides, drafting the agreement until a winwin solution is reached. The result of this service is that the parties reach an agreement with the signing of a joint statement which can be used as a guide if a conflict arises.

KEYWORDS: Community; Corporate Social Responsibility; Mentoring.

\section{ABSTRAK}

Pelaksanaan CSR di Indonesia mencakup tanggung jawab sosial dan lingkungan. Seperti yang dirasakan oleh masyarakat Dusun Klandungan Desa Landungsari Kecamatan Dau Kabupaten Malang yang terdampak atas proses pembangunan home stay oleh salah satu perusahaan komersil di Kabupaten Malang. Diperlukan adanya hubungan simbiosis mutualisme antara pelaku usaha dalam menjalankan usahanya dan begitu pula masyarakat juga dapat beraktifitas dengan baik atas proses pembangunan dan oprasional perusahaan untuk kedepannya. Tujuan Pengabdian ini adalah untuk memberikan sosialisasi serta mendampingi warga atas pemenuhan hak-haknya atas pembangunan dan/atau operasional perusahaan sehingga untuk kedepannya tidak terjadi konflik. Metode yang digunakan adalah mendampingi pertemuan negosiasi para pihak tanpa adanya keberpihakan, penyusunan draft kesepakatan sampai dengan dicapainya kesepakatan yang win win solution. Hasil dari pengabdian ini adalah dicapainya kesepakatan para pihak dengan ditandatanganinya surat pernyataan bersama yang dapat digunakan sebagai pedoman apabila muncul konflik mendatang.

KATA KUNCI: Masyarakat; Pendampingan; Tanggung Jawab Sosial Perusahaan. 


\section{PENDAHULUAN}

Perkembangan dunia bisnis sejalan dengan tuntutan kepada perusahaan untuk bertanggung jawab atas dampaknya terhadap stakeholder, transparansi yang lebih besar dengan memperhatikan risiko non-finansial perusahaan serta dampak sosial. Gagasan bahwa perusahaan harus terlibat dalam praktik bisnis yang bertanggung jawab terhadap masyarakat disebut juga Tanggung Jawab Sosial Perusahaan. Gagasan mengenai Tanggung Jawab Sosial Perusahaan atau Corporate Social Resposibility yang selanjutnya disebut CSR merupakan bisnis yang bertanggung jawab kepada masyarakat dan stakeholder selain tanggung jawab kepada Pemegang Saham atau pemilik modal yang muncul sekitar tahun 1960. Setelah itu CSR mulai berkembang secara global baik pada tataran akademik maupun praktis. Namun demikian pembahasan mengenai CSR juga cukup menjadi perdebatan serta kritik bahwa apakah perusahaan dapat memperluas tanggung jawab yang berkaitan dengan finansial di luar kepada pemegang saham. Namun demikian mayoritas perusahaan secara proaktif berkomitmen untuk turut mengambil bagian dari tanggung jawab sosial dengan keterlibatan perusahaan kepada masyarakat dengan membentuk organisasi khusus untuk mengelola CSR mereka secara efektif baik itu proyek jangka pendek maupun program masyarakat yang berkelanjutan untuk jangka Panjang (Wang et al., 2016).

Telah lebih dari 8.000 perusahaan dari lebih 150 negara menandatangani The United Nations Global Compact yang mencakup isu - isu tentang Hak Asasi Manusia, Standar Ketenagakerjaan, Lingkungan, dan Inisiatif Antikorupsi. Hal tersebut menunjukkan bahwa pembahasan mengenai CSR telah bergeser dari pertanyaan mengenai misi organisasi dan mekanisme terhadap nilai pemegang saham menjadi konsep tanggung jawab sosial mereka. Menurut Scherer dan Palazzo menggambarkan bahwa CSR merupakan istilah payung (umbrella terms) yang berfokus pada peran dan tanggung jawab bisnis kepada masyarakat. Sehingga ada definisi CSR secara umum. Perdebatan lain terhadap CSR adalah Batasan kewajiban yang harus dilakukan oleh perusahaan (Ramasastry, 2015).

Awalnya CSR merupakan bentuk tanggung jawab sosial perusahaan yang dilakukan secara sukarela. Namun seiring dengan berjalannya waktu beberapa negara mulai melakukan legalisasi CSR dengan membuat regulasi kemudian mewajibkan CSR kepada perusahaan dan bukan lagi sukarela. Sehingga banyak negara melalui pemerintah melakukan intervensi terhadap pelaksanaan CSR oleh perusahaan (Berger-Walliser \& Scott, 2018). Pemahaman mengenai CSR menunjukkan konflik yang signifikan dan mendasar mengenai apakah CSR dilakukan secara sukarela atau sebagai suatu kewajiban yang diberikan oleh pemerintah, apakah CSR mencerminkan tanggung jawab moral dan etika ataukah hanya sebagai new tool untuk mengangkat branding perusahaan. Hingga pada akhirnya konflik pemahaman tersebut dapat menghambat perusahaan dan juga pemerintah sebagai penyusun regulasi untuk membangun CSR di suatu negara (Schrempf-Stirling \& Palazzo, 2016). Kepercayaan masyakarat terhadap CSR-pun menurun dan studi menunjukkan bahwa masyarakat menjadi skeptis terhadap kegiatan CSR yang dilakukan oleh perusahaan (Berger-Walliser \& Scott, 2018).

Masyarakat akhinya memiliki peningkatan kesadaran mengenai pentingnya andil perusahaan dalam lingkungan sosial memicu masyarakat perlu untuk mengetahui informasi mengenai aktifitas CSR suatu perusahaan. Informasi atau CSR report tersebut juga tak kalah penting bagi para investor ataupun calon investor dalam pengambilan keputuasan. Rasionalisasi 2.2 pengambilan keputusan oleh investor dan/atau calon investor dapat dilakukan dengan adanya CSR report yang akurat, lengkap dan tepat waktu (Budiman, 2015). Penelitian juga menunjukkan bahwa CSR report tersebut tak hanya penting bagi investor. Dapat dilihat 
dalam peristiwa Tumpahan minyak Exxon Valdez memicu CSR report karena stakeholder perusahaan berharap bahwa Exxon akan melakukan bisnis dengan tetap menjaga kelestarian lingkungan. Namun saat Exxon gagal memenuhi harapan tersebut, CSR report dapat menjadi mekanisme supaya Exxon mendapat Kembali kepercayaan dari masyarakat. Bahkan perusahaan yang belum pernah mengalami peristiwa negative seperti Exxon menemukan bahwa mereka perlu untuk mempublikasikan CSR report mereka sebagai suatu pembelaan terhadap persepsi negative masyarakat. Perusahaan dalam bidang industri berbagaya dan kontroversial sering dianggap bersalah dan CSR report memungkinkan mereka untuk melakukan pembelaan terhadap anggapan bahwa perusahaan mereka telah melakukan kerusakan terhadap dan tidak terbatas pada lingkungan (Shabana et al., 2017).

Muskibah dalam Nita Andriyani Budiman menguraikan bahwa CSR Merupakan suatu pendekatan integrasi kepedulian sosial suatu perusahaan dalam menjalankan bisnis dan interaksi perusahaan dengan para stakeholder berdasarkan prinsip kesukarelaan dan kemitraan. Ruang lingkup CSR mencakup kepatuhan dan kepedulian perusahaan kepada hak asasi manusia, ketenagakerjaan, perlindungan konsumen serta kelestarian lingkungan hidup, serta pembangunan kesejahteraan masyarakat yang berada di sekitar perusahaan (Budiman, 2015). Vilanova mengusulkan bahwa definisi CSR terdiri dari lima dimensi yakni visi, hubungan masyarakat, tempat kerja, akuntabilitas serta pasar. Visi, misalnya, mencakup pengembangan konseptual CSR, kode, dan nilai dalam organisasi. Hubungan masyarakat mencakup kemitraan dengan pemangku kepentingan seperti konsumen, pemasok, dan sebagainya. Tempat kerja mencakup hak asasi manusia dan praktik ketenagakerjaan di dalam organisasi. Akuntabilitas mencakup transparansi dalam komunikasi dan pelaporan keuangan. Pasar mencakup hubungan antara CSR dan proses bisnis inti seperti penjualan, pembelian dan lain - lain (Stuebs \& Sun, 2015).

Saat ini CSR telah menjadi wacana serta kegiatan yang banyak dilakukan oleh perusahaan perusahaan di Indonesia. Guna meningkatkan kepercayaan masyarakat terhadap perusahaan bahwa perusahaan tersebut telah melakukan perbaikan terhadap lingkungan di sekitar perusahaan maka perusahaan memberikan keterbukaan informasi kepada masyarakat mengenai CSR mereka. Keterbukaan informasi mengenai CSR suatu perusahaan dapat memberikan keuntungan tersendiri kepada perusahaan, yakni: pertama, segi ekonomi bahwa terlaksananya CSR perusahaan dapat meningkatkan nilai perusahaan; kedua, segi investasi ditemukan bahwa investor akan lebih mempertimbangkan pengambilan keputusan untuk memberikan investasi kepada perusahaan yang memiliki tingkat kepedualian yang tinggi pada masyarakat dan juga kelestarian lingkungan; ketiga, segi hukum, CSR merupakan bentuk kewajiban yang harus dilakukan dan ditaati oleh perusahaan.

Adanya gagasan CSR menempatkan perusahaan tak hanya bertanggung jawab terhadap nilai perusahaannya saja (kondisi keuangan) atau dikenal dengan istilah single bottom line, tetapi juga tanggung jawab perusahaan harus berpijak kepada triple bottom lines yakni nilai perusahaan, sosial dan juga lingkungan (Budiman, 2015). Pertimbangan etika bisnis guna meningkatkan kualitas hidup bagi karyawan perusahaan beserta keluarganya dan juga masyarakat di sekitar perusahaan dan juga masyarakat secara luas memicu lahirnya aktivitas CSR (Hadi, 2011).

Gagasan CSR di Indonesia sendiri mencakup tanggung jawab sosial dan lingkungan. Adanya regulasi yang mengatur mengenai CSR di Indonesia pada satu sisi memberikan kepastian hukum terhadap pelaksanaan CSR. Namun di sisi lain dengan diaturnya CSR pada beberapa peraturan perundang - undangan sebagaimana dalam table diatas menunjukkan bahwa terdapat tumpeng tindih pengaturan mengenai CSR di Indonesia. 
Salah satunya adalah inkonsistensi penggunaan frasa atau istilah antara satu peraturan perundangan dengan peraturan perundangan yang lain. Inkonsistensi tersebut dapat terjadi karena belum ada konsep dan ruang lingkup yang jelas mengenai CSR itu sendiri di Indonesia. Selain itu subjek yang wajib melaksanakan CSR pun beragam. UUPT Undanghanya membatasi kegiatan CSR untuk Perseroan Terbatas yang bergerak di sektor sumber daya alam, namun peraturan lain meminta perusahaan perorangan atau wiraswasta untuk turut melaksanakannya. Walaupun beberapa undang-undang sektoral seperti lingkungan hidup, kehutanan, minyak dan gas bumi, serta mineral dan batu bara telah mengatur mengenai siapa yang memiliki kewajiban CSR, namun masalah multitafsir muncul dari frasa "mengelola dan memanfaatkan sumber daya alam" atau "berdampak pada fungsi kemampuan sumber daya alam” pada Pasal 74 UUPT (Karjoko et al., 2019).

Bukan hanya itu, perdebatan mengenai legalitas CSR yang bergeser dari aktivitas sukarela menjadi kewajiban yang harus dilakukan oleh perusahaan juga muncul di Indonesia. Sejak kemunculan CSR tahun 2007, konsep kebijakan hukum CSR merupakan suatu kewajiban (bukan sukarela) dan diikuti dengan pemberlakukan sanksi bagi pelanggar (mandatory) terkhusus kepada perusahaan yang bergerak dalam bidang sumber daya alam, sebagaimana tertuang dalam UU Perseroan Terbatas dan UU Pasar Modal (Sefriani \& Wartini, 2017).

Penelitian menunjukkan bahwa ternyata konsep mandatory atau kewajiban yang memberikan sanksi dalam pelaksanaan CSR di Indonesia dinilai efektif dan tepat. Penerapan norma secara sukarela terhadap pelaksanaan CSR di Indonesia belum dapat efektif mengingat kondisi, situasi serta budaya masyarakat Indonesia. Indonesia juga ternyata bukanlah negara satu-satunya yang menerapkan norma CSR sebagai suatu kewajiban diikuti dengan pengenaan sanksi karena beberapa negara juga menerapkan model kebijakan hukum yang hampir sama dengan Indonesia.(Karhu, 2015).

Dari uraian diatas menunjukkan bahwa perusahan memilik tangungjawab kepada lingkungan masyarakat sekitar sebagai tempat pertama yang terimbas dari adanya pembangunan dan/atau operasional perusahaan. Seperti yang dirasakan oleh masyarakat Dusun Klandungan Desa Landungsari Kecamatan Dau Kabupaten Malang yang terdampak atas proses pembangunan home stay oleh salah satu perusahaan komersil di Kabupaten Malang. Diperlukan adanya hubungan simbiosis mutualisme antara pelaku usaha yang dapat dengan baik menjalankan usahanya dan begitu pula masyarakat juga dapat beraktifitas dengan baik atas proses pembangunan dan oprasional perasahan untuk kedepannya. Sebagai perusahaan yang memiliki kewajiban CSR kepada warga serta warga dapat menikmati juga keuntungan atau manfaat atas adanya tempat usaha dilokasinya.

Dalam pelaksanan dari pendampingan ini berupa pendampingan warga atas pemenuhan hak-haknya dari adanya pembangunan dan/atau operasional perusahaan sehingga utnuk kedepannya tidak terjadi permasalahan, semisal atas pembuangan limbah, penyerapan tenaga kerja, tidak berimplikasi pada perkonomian mikro masyarakat sekitar.

\section{METODE}

Solusi dari masalah yang ditawarkan kepada Masyarakat Dusun Klandungan Desa Landungsari Kecamatan Dau Kabupaten Malang yang diharapkan dapat menyelesaikan beberapa persoalan yang dihadapi. Pelaksanaan pengabdian ini dilakukan melalui kegiatan sosialisasi dan pendampingan. Upaya ini diharapkan dari warga dapat mencapai apa yang 2.2 dikehendaki berdasarkan hak-haknya yang rasional sehingga dapat diterima dengan baik oleh pemilik perusahaan, sehingga diharapkan pada tujuan dari kesepakatan dari kedua belah pihak secara win-win solution. Adanya kesepakatan itu merupakan wujud dari alternative 
dispute resolution (ADR) dalam penyelesaian sengketa antar kedua belah pihak, melihat efek dan dampak penyelesaian sengketa secara peradilan kurang memuaskan oleh para pihak yang bersengketa, oleh karena itu musyawarah menjadi satu cata terbaik dalam penyelesain sengketa dengan baik karena mengedepankan adanya itikad baik dari para pihak.(Wiguna, 2018)

Berikut alur sistematika dalam pemecahan permasalahan masalah dalam Iptek bagi Masyarakat Dusun Klandungan Desa Landungsari Kecamatan Dau Kabupaten Malang:

Gambar 1.

Gambaran

Iptek Alur

Penyelesaian

Permasalahan

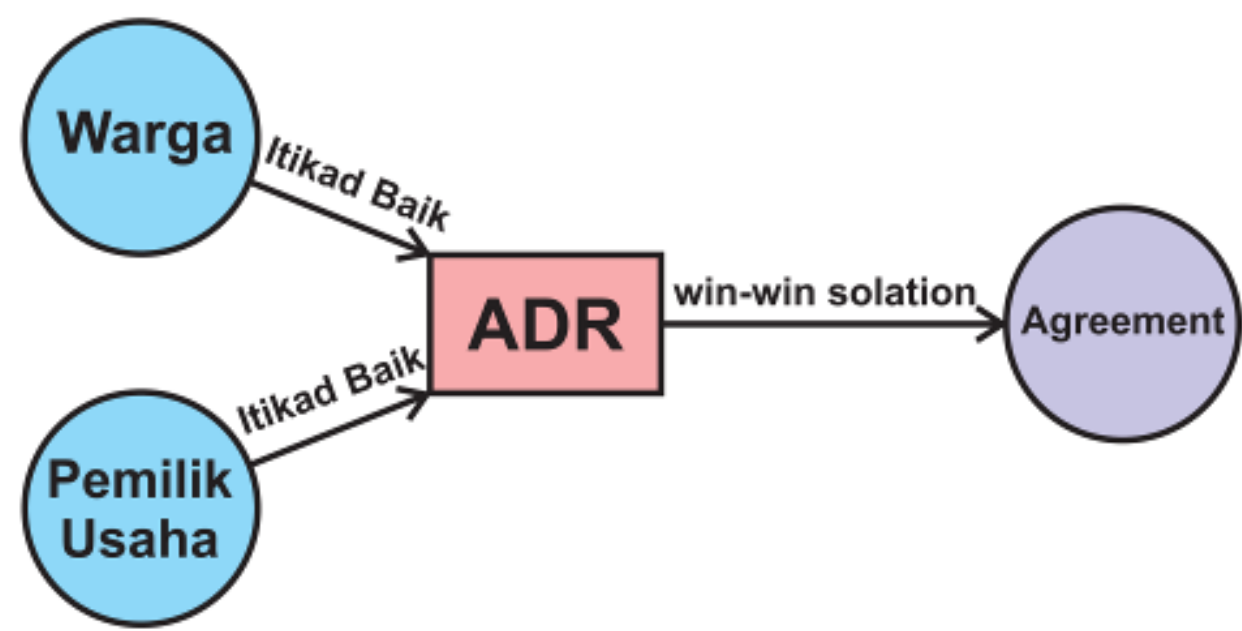

Berdasarkan gambar diatas, masyarakat berperan aktif diberikan pemahaman terkait hakhaknya sebagai lingkungan yang terdampak dalam pembangunan dan operasional usaha dan pengusaha diberikan pemahaman terkait kewajiban tanggungjawab sosial atas operasional usahanya. Dengan didasarkan atas itikad baik untuk terwujudnya kebaikan kepentingan bersama diwujudkan berupa musyawarah yang rasional dan win-win solution, sehingga dapat mendapatkan sebuah kesepaktan yang baik bagi kedua belah pihak tanpa ada yang dirugikan.(Nurwullan \& Siregar, 2020)

Pelaksanaan pada pengabdian ini, mitra berperan aktif untuk meminta kepada pengusul untuk melakukan pendampingan dalam proses negosiasi ini sampai proses drafting kesepakatan yang disepakatai oleh kedua belah pihak. Adapun melalui penggunaan IPTEK ini dapat menguragi dampak yang negative baik bagi kedua belah pihak, dikarenakan proses seperti ini mempunyai resistensi potensi konfik yang tinggi antara warga dan pemilik usaha. Kecenderungan pola komunikasi destruktif akan terjadi, jika tidak didasari atas itikad baik dari kedua belah pihak.(Hidayatullah et al., 2016)

\section{HASIL DAN PEMBAHASAN}

Pelaksanaan pengabdian ini merupakan upaya dalam mendampingai masyarakat dengan tujuan meredam adanya konflik yang destruktif antara warga dan pemilik usaha, sehingga harapan dari kegiatan ini bertujuan terjadinya kesepakatan atas dampak dari pembangunan usaha ini dapat diselesaikan dengan baik. Secara hasil penelitian dari Chatarina Candra Murti menunjukkan adanya dampak pembangunan usaha penginapan berupa dampak lingkungan fisik, sosial, ekonomi, dan fisik, untuk dampak lingkungan secara fisik adalah beralihnya fungsi lahan, perubahan kondisi air, dan penambahan limbah. (Murti \& Rofi, 2017) Dampak sosial adalah warga akan terdesak dengan perubahan kultur budaya dan sedangkan dampak ekonomi selain secara postiif menambah lapangan kerja untuk warga

\section{Janayu} 2.2 
sekitar, namun juga dampak negatif terkait usaha kos milik warga akan tergerus dengan adanya usaha penginapan tersebut.(Murti \& Rofi, 2017).

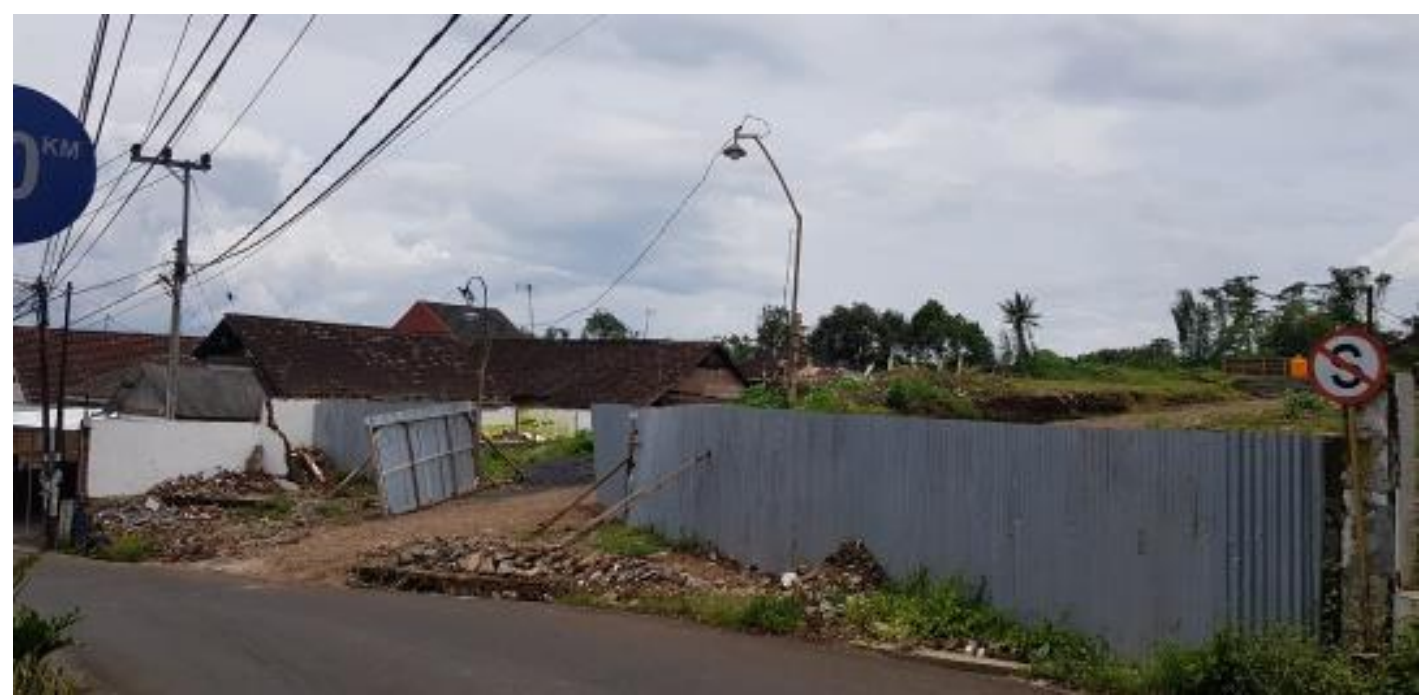

Gambar 2.

Lokasi

Pembangunan

Tempat Usaha

Kegiatan pengabdian ini dijalankan bersam mitra dengan posisi pengusul hanya bersifat pasif merespon dari usulan aktif warga, mengingat persolaan ini menjadi sengketa yang mengharuskan secara aktif harus warga dalam pengambilan keputusan. Sifat dari pengusul disini hanya bertindak sebagai penasihat yang hanya memaparkan paparan atas pertanyaan dari warga, sehingga posisi pengusul menjadi problem solving bukan justru menjadi provokator yang menjadi penggerak warga untuk meminta haknya kepada pemilik usaha.

Melihat dari lokasi pembangunan tersebut terletak dipadat penduduk dan diposisi tanah yang lebih tinggi dengan lokasi rumah warga sekitar, secara konsekuensi dapat menimbulkan dampak lingkungan yang serius kepada warga sekitar sehingga perlu adanya kesepatakan yang baik dari kedua belah pihak supaya kedepannya tidak terdapat kesalahpahaman yang berdampak pada potensi konflik.

Janayu

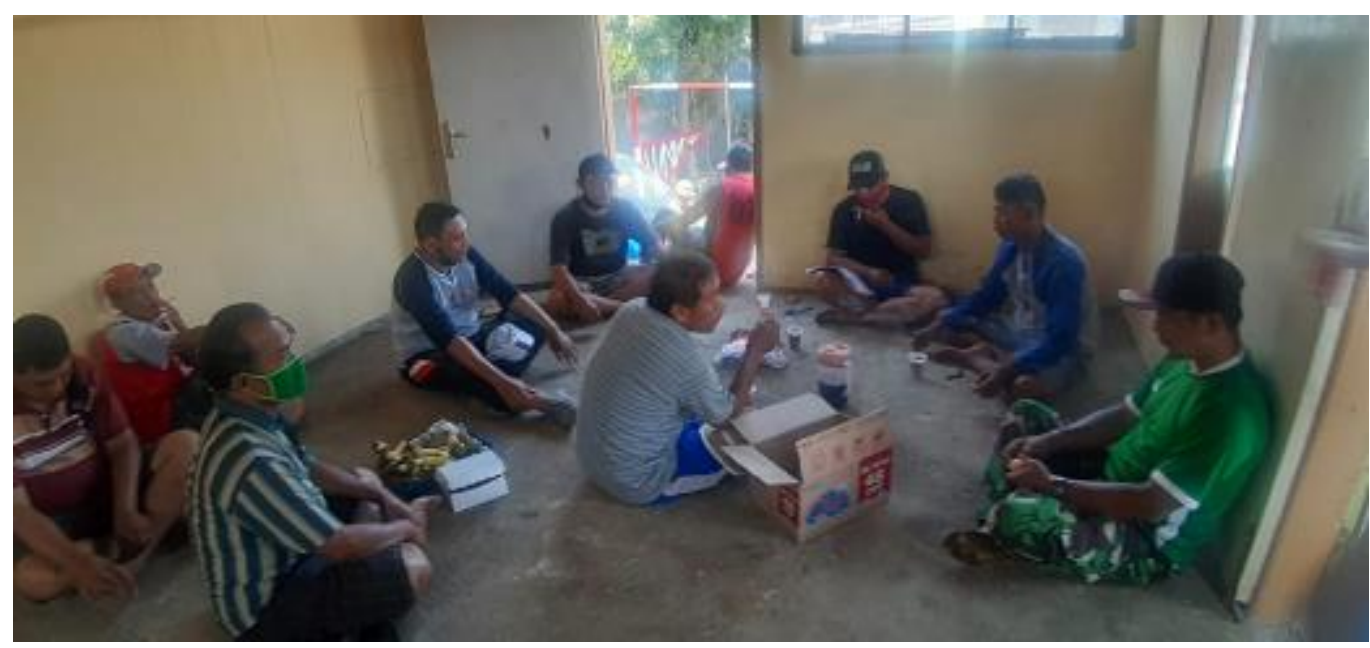

Gambar 3.

Musyawarah Antara Warga dengan Pemilik Usaha 
Gambar 4.

Peninjauan

Lokasi Antara

Warga dengan

Pemilik Usaha

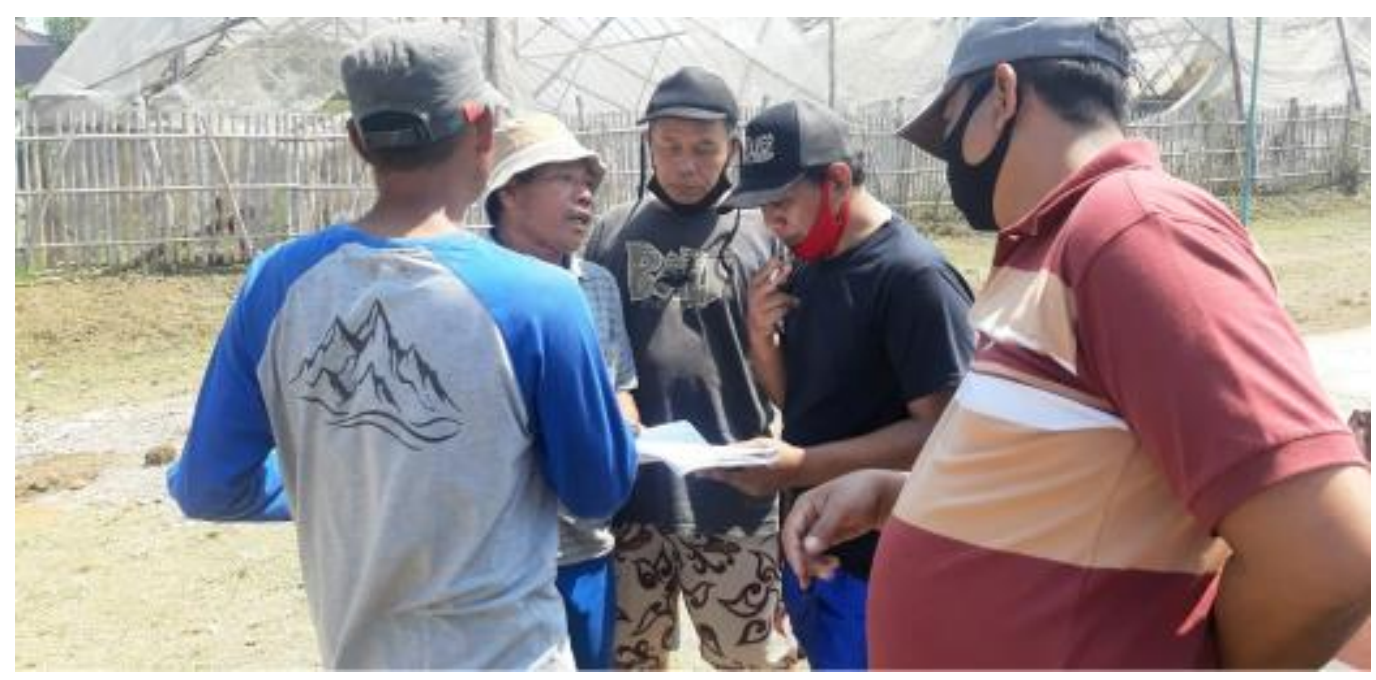

Pada proses pelaksanaan dilakukan musyawarah dengan kedua belah pihak untuk mendapatkan hasil yang baik, seperti dalam hal hal-hal yang diminta oleh warga adalah:

1. Kesediaan untuk memenuhi seluruh legalitas perijinan dan bertanggung jawab penuh terhadap pengolahan limbah, sampah secara mandiri;

2. Kesediaan untuk untuk membuat Dokumen Upaya Pengelolaan Lingkungan Hidup dan Upaya Pemantauan Lingkungan Hidup (UKL-UPL) yang mengacu pada peraturan yang berlaku;

3. Bertanggungjawab sistem drainase atau pembuangan air;

4. Bahwa pembangunan usaha penginapan memberikan prioritas penerimaan tenaga kerja kepada warga lingkungan sekitar sesuai dengan keahlian yang dimiliki;

5. Berkontribusi dan berperan aktif dalam kegiatan warga sekitar.

Pada tahap akhir dari musyawarah tersebut, agar kesepakatan tersebut menjadi kesepakatan yang mengikat kedua belah pihak dituangkan dalam bentuk surat pernyataan yang ditanda tangani oleh kedua belah pihak. Sehingga kedepannya jika terdapat permasalahan dapat kembali mengacu kepada kesepatan tertulis itu. Namun tidak menutup kemungkinan akan diadakan musyawarah kembali antar kedua belah pihak dikedepannya. Penyelesaian permasalahan ini jika tidak diselesaikan dengan baik dapat berpotensi besar muncul konflik yang berdampak pada konflik sosial, dengan pola musyawarah dan itikad baik sesuai dengan diharapkan terjadinya kesepakatan bersama tanpa merugikan salah satu pihak.

\section{SIMPULAN}

Pelaksanaan pengabdian ini mulai tahap awal sampai akhir dilaksanakan secara aktif oleh mitra dan posisi pengusul berada di luar tanpa ada pemihakan kepada salah satu pihak, kedudukan penngusul memaparkan paparan dan pendapat sesuai dengan hukum yang berlaku di Indonesia. Oleh karena itu menjadikan upaya penyelesaian persoalan dampak pembangunan usaha penginapan ini dapat berjalan dengan baik dan posisi pengusul diposisikan sebagai problem solving oleh kedua belah pihak. Hasil dari keseluruh kegiatan ini selesai dengan adanya kesepatan tertulis antar kedua belah pihak dan dapat diterima dengan baik tahap merasa ada yang dirugikan. Permasalahan yang muncul dari pelaksanaan pengabdian ini adalah perlu ada kesabaran dan membuang keinginan sepihak harus didasarkan pada itikad baik dan keinginan yang realitis, sehingga diperlukan pemberian pemahaman kepada maisng-masing pihak atas hak dan kewajiban berdasarkan peraturan

\section{Janayu} 2.2 
yang berlaku. Adanya potensi konflik sosial yang dapat terjadi menjadikan proses pengabdian ini perlu dilakukan dengan hati-hati dan pemahaman atas karakter dari masingmasing pihak.

\section{DAFTAR PUSTAKA}

Berger-Walliser, G., \& Scott, I. (2018). Redefining corporate social responsibility in an era of globalization and regulatory hardening. American Business Law Journal, 55(1), 167218. https://doi.org/10.1111/ablj.12119

Budiman, N. A. (2015). FAKTOR-FAKTOR YANG MEMPENGARUHI PENGUNGKAPAN TANGGUNG JAWAB SOSIAL PERUSAHAAN. Jurnal Riset Akuntansi Mercu Buana, 1(1), 14-34.

Hadi, N. (2011). Corporate Social Responsibility. Graha Ilmu.

Hidayatullah, Umar, Hartati, S. R., \& Arsal, T. (2016). Analisis Peta Konflik Pembangunan Pabrik Pt. Semen Indonesia Di Kecamatan Gunem Kabupaten Rembang. Solidarity: Journal of Education, Society and Culture, 5(1), 10-21.

Karhu, J. (2015). Corporate Social Responsibility and the Law. Review of Market Integration, 7(1), 62-74. https://doi.org/10.1177/0974929215593877

Karjoko, L., Santosa, J., \& Rachmi Handayani, I. G. A. K. (2019). Disfungsi Peraturan Perundang-Undangan Tanggung Jawab Sosial dan Lingkungan di Indonesia. Jurnal Hukum Ius Quia Iustum, 26(2), 305-325. https://doi.org/10.20885/iustum.vol26.iss2.art5

Murti, C. C., \& Rofi, A. (2017). Dampak Sosial Ekonomi dan Lingkungan Fisik Masyarakat Akibat Pengembangan Hotel di Kota Yogyakarta. Jurnal Pembangunan Wilayah Dan Kota, 13(2), 165-174. https://doi.org/10.14710/pwk.v13i2.15830

Nurwullan, S., \& Siregar, H. F. (2020). Asas Konsensualisme Dalam Penambahan Klausula Kontrak Berdasarkan Prinsip Itikad Baik. Proceedings Universitas Pamulang, 1(1). http://www.openjournal.unpam.ac.id/index.php/Proceedings/article/view/5210

Ramasastry, A. (2015). Corporate Social Responsibility Versus Business and Human Rights: Bridging the Gap Between Responsibility and Accountability. Journal of Human Rights, 14(2), 237-259. https://doi.org/10.1080/14754835.2015.1037953

Schrempf-Stirling, J., \& Palazzo, G. (2016). Upstream Corporate Social Responsibility: The Evolution From Contract Responsibility to Full Producer Responsibility. Business and Society, 55(4), 491-527. https://doi.org/10.1177/0007650313500233

Sefriani, \& Wartini, S. (2017). Model Kebijakan Hukum Tanggung Jawab Sosial Perusahaan di Indonesia. Jurnal Hukum IUS QUIA IUSTUM, 24(1), 1-28. https://doi.org/10.20885/iustum.vol24.iss1.art1

Shabana, K. M., Buchholtz, A. K., \& Carroll, A. B. (2017). The Institutionalization of Corporate Social Responsibility Reporting. Business and Society, 56(8), 1107-1135. https://doi.org/10.1177/0007650316628177

Janayu

Stuebs, M., \& Sun, L. (2015). Corporate governance and social responsibility. International Journal of Law and Management, 57(1), 38-52. https://doi.org/10.1108/IJLMA-04-20140034

Wang, H., Tong, L., Takeuchi, R., \& George, G. (2016). Corporate social responsibility: An 
Kurniawan \& Hapsari, Pendampingan Masyarakat Dusun ...

overview and new research directions. Academy of Management Journal, 59(2), 534-544. https://doi.org/10.5465/amj.2016.5001

Wiguna, M. O. C. (2018). Peluang Penyelesaian Sengketa Perdata Tentang Tanah. MasalahMasalah Hukum, 47(1), 47-55. https://ejournal.undip.ac.id/index.php/mmh/article/view/16700 